Gut, 1988, 29, 1692-1698

\title{
Ultrastructural changes in internal anal sphincter in neurogenic faecal incontinence
}

\author{
M SWASH, A GRAY, D Z LUBOWSKI, AND R J NICHOLLS \\ From the Sir Alan Parks Physiology Department, St Mark's Hospital and Institute of Pathology, The London \\ Hospital Medical College, London
}

\begin{abstract}
SUMmaRY The ultrastructural features of the internal anal sphincter (IAS) muscle were studied in biopsies from five patients with neurogenic anorectal incontinence and six control subjects undergoing anorectal excision for cancer, or for inflammatory bowel disease. In the patients with idiopathic neurogenic anorectal incontinence the internal anal sphincter showed loss of smooth muscle cells, disruption of the normal relationships of the remaining cells, stretching of elastic tissue, and increased collagen fibril content. These ultrastructural changes in the morphology of the internal anal sphincter, although probably not the primary cause of faecal incontinence, have functional relevance in the clinical syndrome, as shown by the reduction in resting anal canal pressure found in some patients with this syndrome.
\end{abstract}

In most women with idiopathic neurogenic anal incontinence there is denervation and partial compensatory reinnervation of the striated sphincter muscles of the pelvic floor - that is, of the puborectalis and external anal sphincter muscles. ${ }^{1-5}$ This is the primary abnormality in this disorder. ${ }^{\circ}$ Anorectal manometric studies, however, show that resting tone in the anal sphincter region is reduced in about two thirds of patients with anorectal incontinence. ${ }^{78}$ As about $80 \%$ of resting tone in the anal canal is the result of IAS activity ${ }^{11}$ this observation implies that there is also an abnormality in IAS function in many patients with neurogenic anorectal incontinence. ${ }^{11}$ In this report we describe the ultrastructural abnormalities found in the IAS muscle in neurogenic anorectal incontinence and compare them with the ultrastructural features of the normal human IAS muscle.

\section{Methods}

PATIENTS

Seven control subjects, consisting of four men and three women aged $31-76$ years (mean 52 years), and

Address for correspondence: Dr M Swash, St Mark's Hospital, City Road London E1V 2PS.

Received for publication 1 July 1988. six women aged $36-82$ years (mean 55 years) with idiopathic neurogenic anorectal incontinence were studied." The latter patients all had incontinence to formed stools. None had anorectal prolapse or other anorectal disorder. The control subjects were undergoing excision of the anorectum for low rectal cancer (three patients) or ulcerative colitis (four patients). All the control patients had normal faecal continence; in one continence had been normal before colectomy with defunctioning of the rectum. There was no history of anorectal disease in the control subjects. Biopsies were taken with the informed consent of the patients, and with the agreement of the Combined Ethical Committee of St Mark's and St Bartholomew's Hospitals.

The incontinent patients all showed an increased fibre density $(>1.7)$ in the external anal sphincter muscle in single fibre EMG recordings, ${ }^{3}$ and two had an increased mean pudendal nerve terminal motor latency $(>2.4 \mathrm{~ms}) .^{12-14}$ In the control subjects these investigations were normal. ${ }^{12-15}$ The resting anal pressure $^{75}$ was significantly $(\mathrm{p}<0.01)$ lower in the incontinent patients $(33(15)(\mathrm{SD}) \mathrm{cm}$ water) than in the controls (69 (17) (SD) $\mathrm{cm}$ water). The squeeze anal pressure ${ }^{614}$ was also lower $(p<0.01)$ in the incontinent patients $(61(7)(\mathrm{SD}) \mathrm{cm}$ water) than in the controls (159 (31) (SD) cm water). These results, 


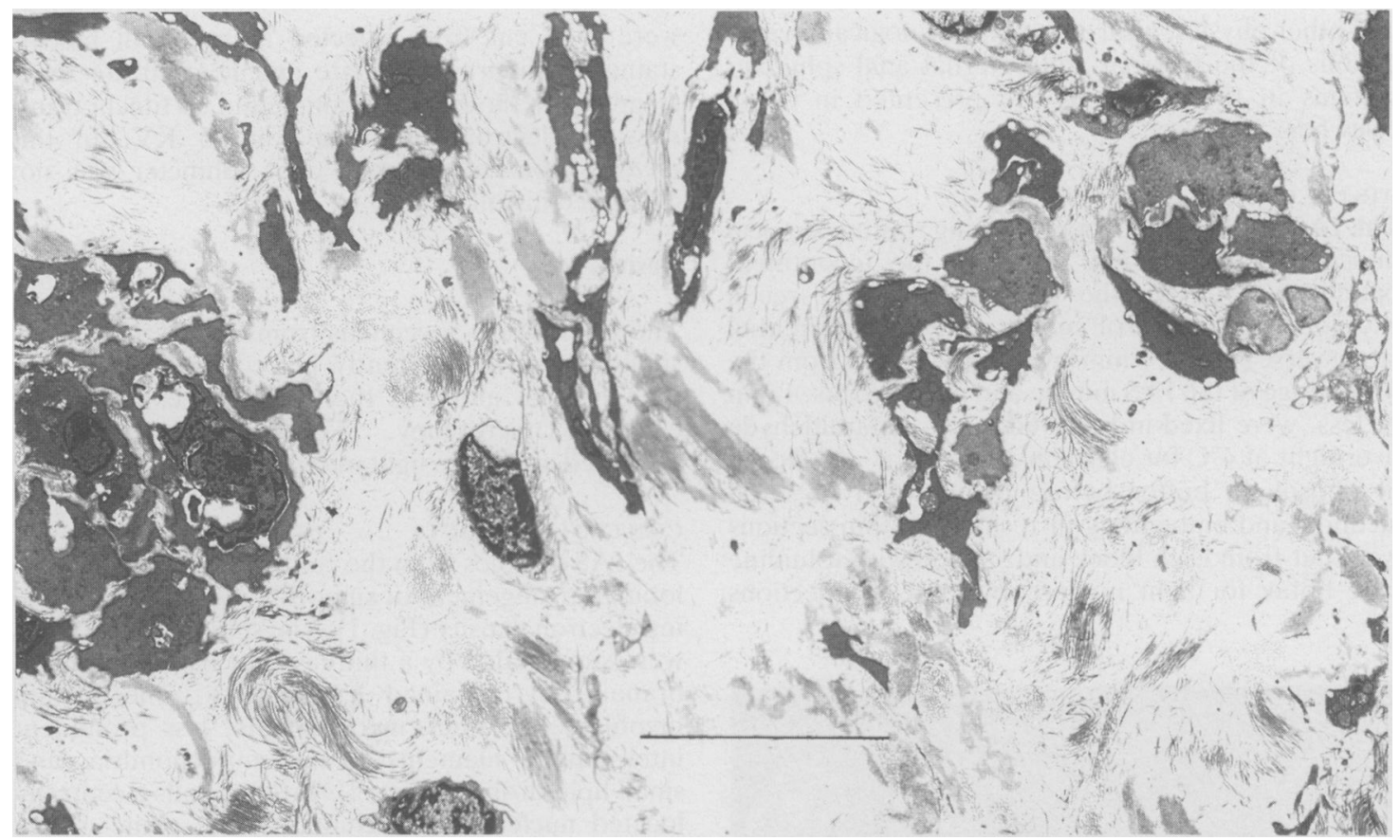

Fig. 1 Internal anal sphincter muscle in aged control subject. Lobular arrangement of smooth muscle cells is present, but there are increased amounts of collagen in the interstitial spaces. There is marked variability in size and electron density of the smooth muscle cells. Bar $10 \mu \mathrm{m}$.
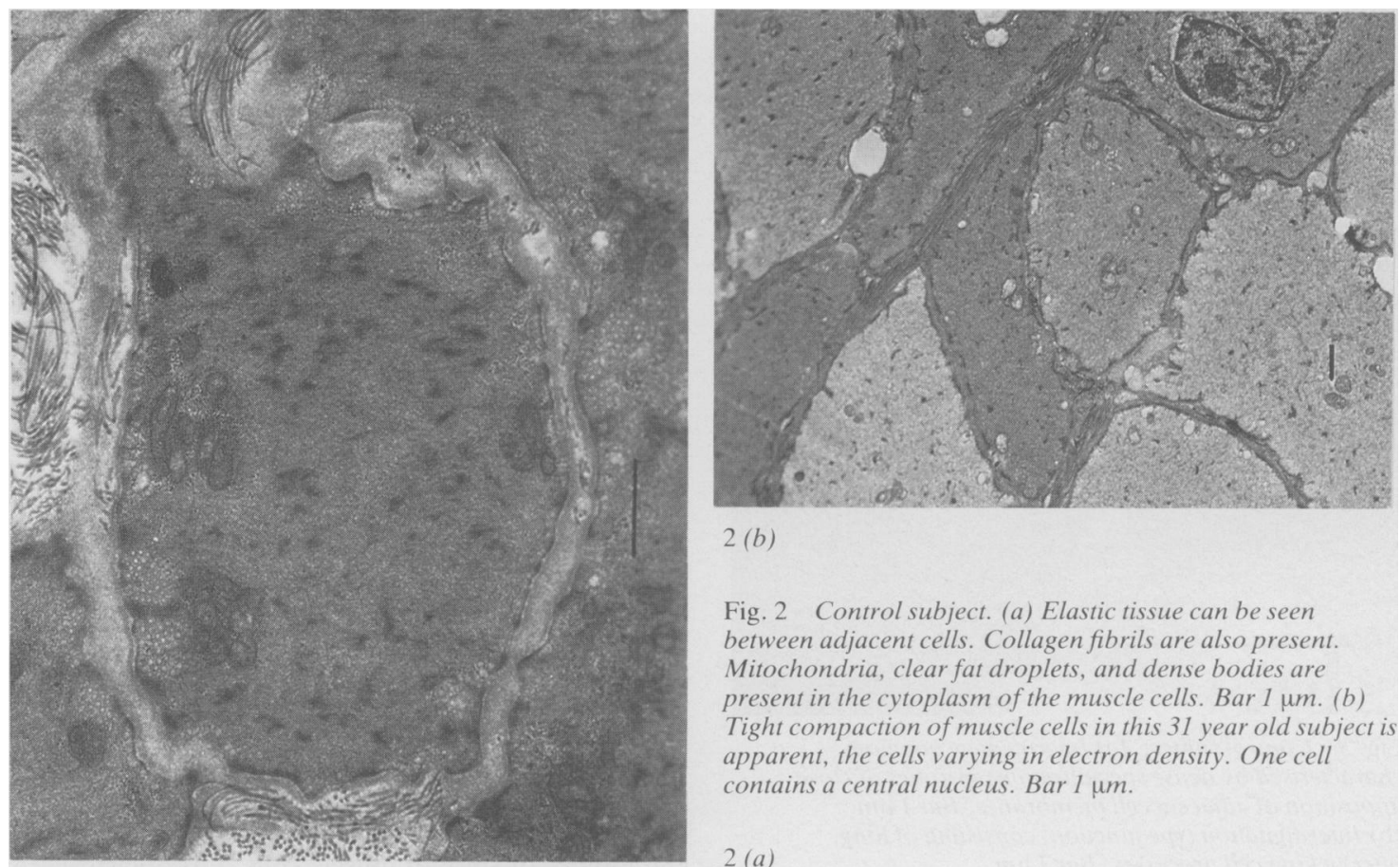

2 (b)

Fig. 2 Control subject. (a) Elastic tissue can be seen between adjacent cells. Collagen fibrils are also present. Mitochondria, clear fat droplets, and dense bodies are present in the cytoplasm of the muscle cells. Bar $1 \mu \mathrm{m}$. (b) Tight compaction of muscle cells in this 31 year old subject is apparent, the cells varying in electron density. One cell contains a central nucleus. Bar 1 um. 
and other physiological and pharmacological investigations of the internal and external anal sphincter systems in these patients are presented in detail elsewhere."

\section{HISTOLOGICAL METHODS}

The IAS muscle was exposed during routine surgical dissection for postanal repair in the incontinent patients, or during the perineal phase of rectal excision in the control subjects. A circumferential (transverse) strip $10 \mathrm{~mm}$ by $3 \mathrm{~mm}$ was cut from the lower edge of the IAS muscle and small blocks, $1 \mathrm{~mm}$ or less, were fixed in buffered $2.5 \%$ glutaraldehyde overnight at $4^{\circ} \mathrm{C}$ for electron microscopy and stored in phosphate buffer before dehydration in serial alcohols and embedding in resin. Semithin sections were cut from each block and stained with toluidine blue botax for light microscopy, and thin sections

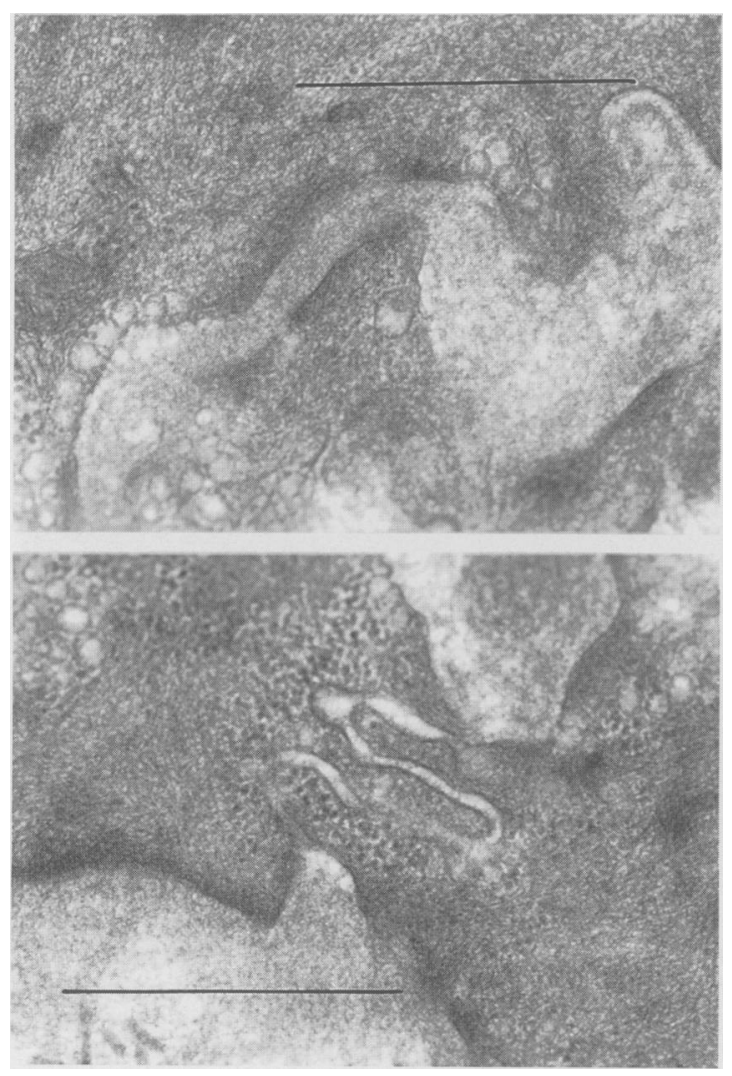

Fig. 3 Control subject. (a) Intermediate junctions characterised by dense specialisations in zones of close apposition of adjacent cell membranes. Bar l $\mathrm{\mu m}$. (b) Interdigitation type junction, consisting of long, interlocking cell processes. Bar $1 \mu \mathrm{m}$. were then cut from selected areas of all blocks, stained with uranyl acetate and lead citrate using standard methods, and examined in a Hitachi transmission electron microscope at $75 \mathrm{KV}$. In this investigation the external anal sphincter was not examined histologically.

\section{Results}

The IAS muscle specimens from one of the control subjects was inadvertently placed in buffer rather than fixative and was therefore not examined by electron microscopy. This biopsy, however, appeared normal in light microscopic studies.

\section{CONTROL. SUBJECTS}

The IAS samples from the control subjects showed a lobular arrangement of smooth muscle cells of varying electron density (Fig. 1). The smooth muscle cells were surrounded by a thin layer of basement membrane. They contained dense bodies, zones of thin myofilaments, thick myofilaments, less prominent intermediate filaments, scanty mitochondria, and small lipid droplets (Fig. 2). In some cells a centrally located nucleus was included in the plane of the section (Fig. 1). The smooth muscle cells varied in their electron density, some appearing darker than others (Fig. 2). Individual smooth muscle cells were in close apposition, separated by thin skeins of collagen fibrils. Bands of elastic fibrillar material were seen connecting muscle cells to each other, and to their adjacent connective and collagen tissue (Fig. 2).

Four types of cell to cell junction were observed, as in smooth muscle cells in other parts of the gut and in other organs ${ }^{1017}$ - for example, in blood vessels. ${ }^{1 \times}$ These consisted of non-specialised appositions, in which the adjacent plasma membranes of two cells ran parallel with each other, about $10 \mathrm{~nm}$ apart (Fig. 3 ); intermediate contacts, characterised by electron dense material on the cytoplasmic aspect of adjacent cell membranes, about $50 \mathrm{~nm}$ apart (Fig. 3); interdigitations, consisting of complex contacts between long, interdigitating cell processes derived from the membranes of the two adjacent cells and often containing intermediate contacts (Fig. 3); and nexus or gap junctions consisting of pores interconnecting two adjacent cells through a region of dense specialisation of the two adjacent cell membranes (Fig. 2). The dense regions in the plasma membranes associated with intermediate cell contacts resembled the dense bodies seen in the cytoplasm. Caveolae were a prominent feature of the plasma membranes of the smooth muscle cells.

Capillaries were recognised between and within the lobules of smooth muscle cells. Fibroblasts were 


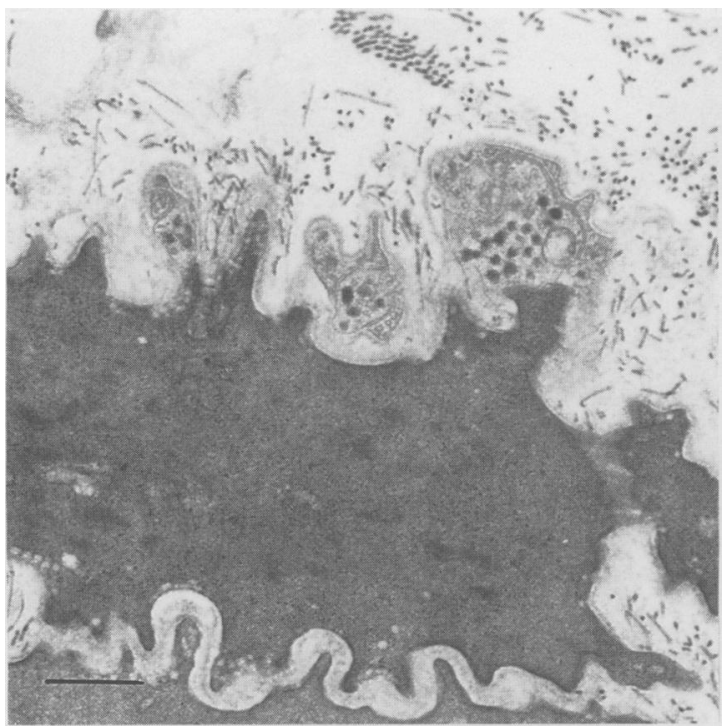

Fig. 4 Control subject. A non-myelinated axon closely approaches a smooth muscle cell, but does not make synaptic contact with it. The axon contains electron dense vesicles. Bar l $\mu \mathrm{m}$.

scanty. Nerve fibre bundles were seen in two of the control IAS muscle samples, consisting of clusters of small unmyelinated axons of varying diameter, and a few small myelinated nerve fibres, interspersed with connective tissue and periaxial cells. Isolated single axons were sometimes seen in close relation to muscle cells, but nerve axons were never seen to make synaptic contact with smooth muscle cells, although some contained electron dark or light vesicles in these regions of close nerve/muscle cell apposition (Fig. 4).

EFFECT OF AGE

The IAS samples taken from the two oldest control subjects (Fig. 1) showed a less compacted arrangement of muscle fibres, with increased amounts of collagen in the interstices between the smooth muscle cells and with some dark, small cells resembling those seen in the IAS muscle biopsies from the incontinent patients. This separation of muscle cells with increasing age was associated with fewer zones of cell contact, and with some stretching of elastic tissue strands.

INCONTINENT PATIENTS

The IAS muscle biopsies from the patients with neurogenic faecal incontinence showed striking differences from the control material. The normal lobular architecture of the muscle was absent (Fig.

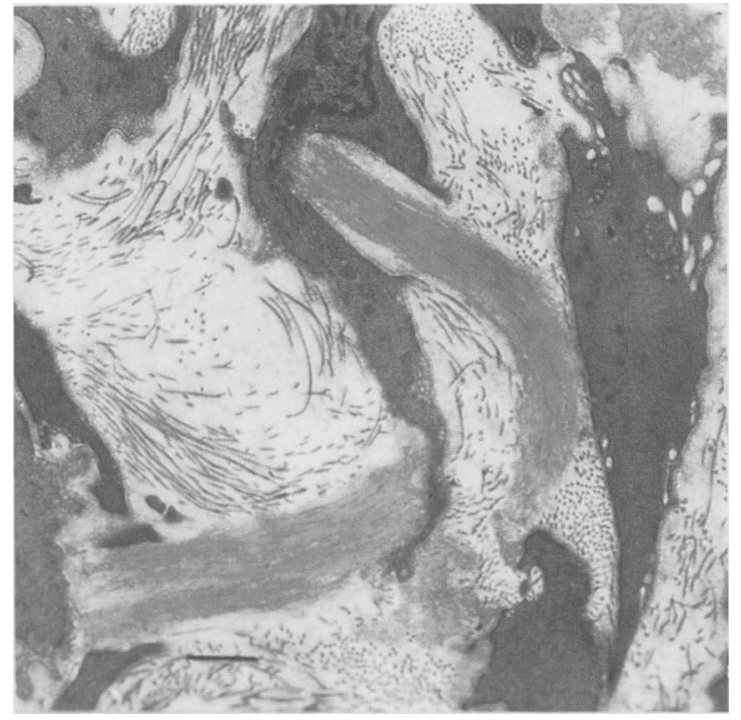

Fig. 5 Incontinent patient. Smooth muscle cells are widely separated, more linear and darker than normal. Strands of elastic tissue are stretched between them, and there are increased numbers of collagen fibrils. Some intercell junctions remain. Bar $1 \mu \mathrm{m}$.

5). In addition, there was a marked reduction in the number of smooth muscle cells, with abnormally marked separation of the remaining cells. The latter appeared small, attenuated, irregular and electron dense, or pale and vesicular (Fig. 6). The variance in electron density of the muscle cells was greater in the IAS muscle biopsies from the incontinent patients than from the control subjects. There were relatively few zones of cell contact, reflecting the increased separation of individual muscle cells and elastic tissue bands, when present, were stretched across the intervening spaces between the remaining fibres (Fig. $5)$. There was a marked increase in number of collagen fibres, filling the intercellular space, and fibrocytes were frequent in these zones (Fig. 6). Some tortuous empty wraiths of basal lamina were recognised in the interstitial spaces, suggesting loss of smooth muscle cells (Fig. 6).

There were no inflammatory cells. Blood vessels were relatively sparse, and nerve fibres were seen in only one of the biopsies from the incontinent patients. In addition to smooth muscle cells, one biopsy contained striated muscle fibres, derived from the neighbouring external anal sphincter muscle. These striated muscle fibres showed marked variability in fibre size, with abnormalities in the arrangement of myofilaments in the cross-sectional area of the fibres." 


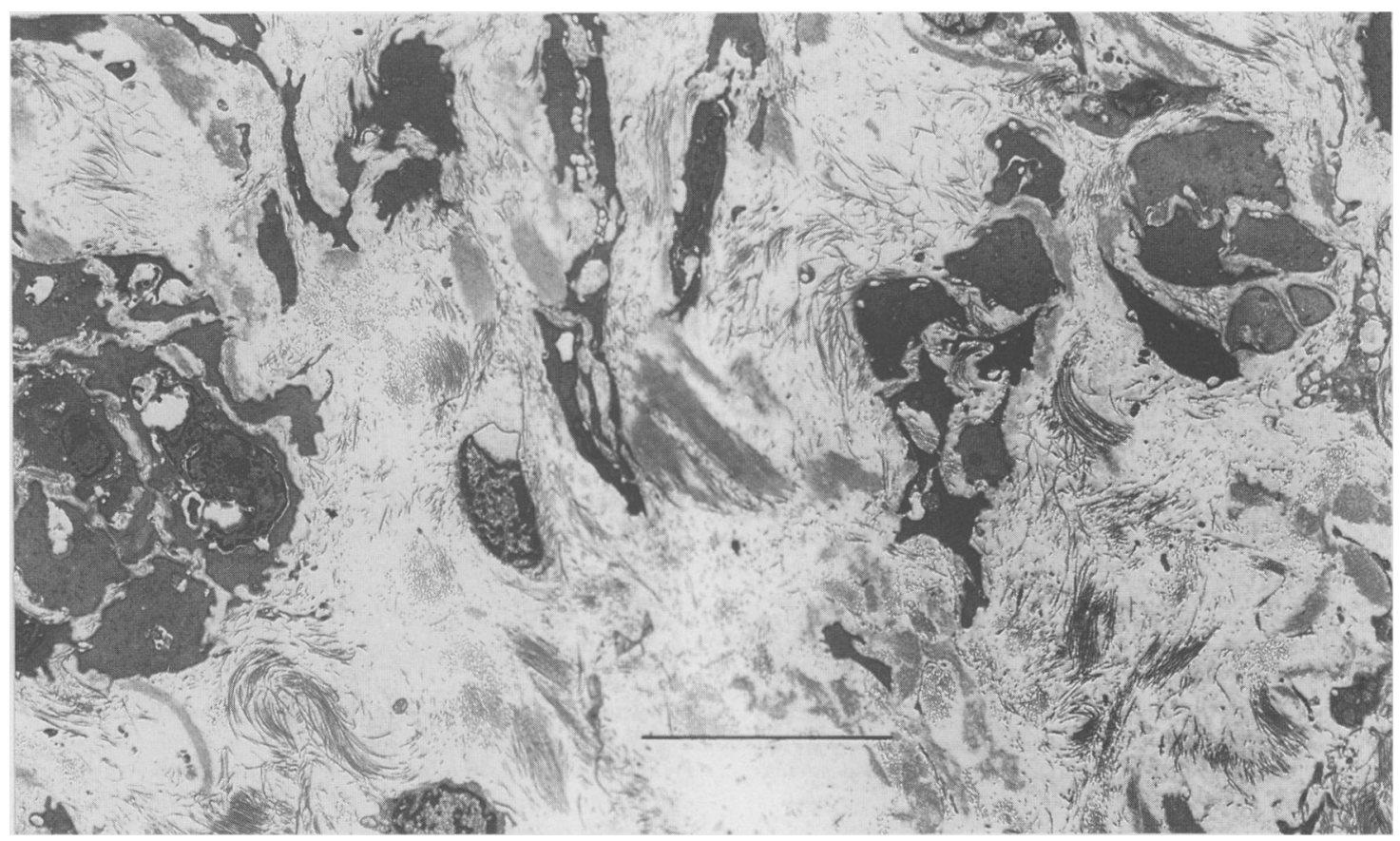

Fig. 6 Incontinent patient. There is marked loss of smooth muscle cells, with fragmentation of elastic tissue, and an increase in the number of collagen fibrils. Remaining smooth muscle cells are abnormal in shape and electron density. Bar $10 \mu \mathrm{m}$.

\section{Discussion}

Smooth muscle cells are thought to be of similar histological type in all parts of the intestine, although varying in their longitudinal, spiral, or circular arrangement in relation to the specialised sphincter zones. ${ }^{1619}$ In this study the histological features of smooth muscle cells in the IAS biopsies from the control subjects resembled those of smooth muscle from other parts of the gut. ${ }^{19}$ Nerve fibres were seen in the IAS muscle biopsies in two of the control subjects and in one of the incontinent patients, but these nerve fibres did not make direct synaptic contact with smooth muscle cells. ${ }^{19}$ In parts of the nerve fibres studied in close relation to muscle cells, however, there were vesicles of electron dense or light type.

In the IAS biopsies from the patients with faecal incontinence smooth muscle cells were separated by dense collagen fibrils, and there were redundant rings of basal lamina suggesting loss of muscle cells. Many of the remaining smooth muscle cells appeared atrophic, angulated and more electron dense than normal, and in some biopsies there was striking stretching of the elastic tissue strands that normally connect adjacent muscle cells. There were no features suggestive of inflammation, or of penetrating injury to the IAS muscles. The samples from the two oldest control subjects showed less marked abnormalities that in some respects resembled those seen in the incontinent patients.

The clinical investigations carried out in these patients before IAS muscle biopsy showed abnormalities consistent with damage to the pudendal innervation of the external anal sphincter muscle, as has been shown in previous studies of this problem. ${ }^{6712-14}$ In addition, the mean resting pressure in the anal canal was moderately reduced compared with the control subjects and to the normal values established in our laboratory. ${ }^{\circ}{ }^{15}$ This observation is consistent with weakness of the IAS muscle because about $80 \%$ of resting tone in the anal canal is provided by the tonic action of this muscle, rather than from resting contraction of the voluntary external anal sphincter muscle." pressure in this region, on the other hand, is a function of contraction of the external anal sphincter ${ }^{711} 15$ and this, also, was reduced.

The ultrastructural abnormalities we have found in the IAS muscle are of uncertain origin. They may be because of mechanical injury to this muscle in the absence of the normal support of the external anal 
sphincter ring..$^{20}$ We have also reported pharmacological abnormalities in these IAS muscles consistent with damage to the autonomic innervation of this muscle, " but these changes could themselves be secondary to mechanical factors within the abnormal muscles. Loss of IAS muscle tone in the presence of denervation of the striated sphincter muscles in anorectal incontinence is by no means inevitable. Internal anal sphincter muscle tone is often retained in the presence of severe denervation and weakness of the external anal sphincter muscle,$^{67}$ indicating that the internal and external anal sphincters can function independently, and are not necessarily susceptible to damage from the same causes.

The relative roles of dysfunction in the internal and external anal sphincter muscles in faecal incontinence are controversial. Clearly, there must be synergy between the actions of the non-striated, involuntary muscles and striated, voluntary muscles in the maintenance of normal continence and during defaecation. Current views indicate that the external anal sphincter and puborectalis muscles are the major muscular components in the maintenance of continence, and that defecation can only occur when these muscles relax. The anal canal is thus opened by sphincteric relaxation and by straightening of the anorectal angle, unlocking the valvular mechanism at the anorectal junction. ${ }^{621}$ It is our view that several factors contribute to normal faecal continence, ${ }^{22-24}$ including the internal and external anal sphincters, the puborectalis muscle, the motility of the colon and anorectum, and faecal consistency. In addition, sensory feedback from the anal sensory receptors ${ }^{25}$ is important in determining the level of activity of the striated components of the anal sphincter mechanism. ${ }^{26}$ The inter-relationships of these factors in faecal continence and incontinence, however, remain uncertain.

We thank the St Mark's Research Foundation for continuing financial support. Mr Lubowski was supported by a grant from the Royal Australasian College of Surgeons. This work was presented at a meeting of the Pathological Society of Great Britain and Ireland held in London in January 1988.

\section{References}

1 Parks AG, Swash M, Urich H. Sphincter denervation in anorectal incontinence and rectal prolapse. Gut 1977; 18: $656-65$.

2 Beersiek F, Parks AG, Swash M. Pathogenesis of anorectal incontinence; a histometric study of the anal sphincter musculature. J Neurol Sci 1979; 42: 111-27.
3 Neill ME, Swash M. Increased motor unit fibre density in the external anal sphincter muscle in anorectal incontinence; a single fibre EMG study. J Neurol Neurosurg Psychiatry 1980; 43: 343-7.

4 Bartolo DCC, Jarratt JA. Read MG, Donnelly TC, Read NW. The role of partial denervation of the puborectalis muscle in idiopathic faecal incontinence. Br J Surg 1983; 70: 664-7.

5 Womack NR, Morrison JFB, Williams NS. The role of pelvic floor denervation in the aetiology of idiopathic faecal incontinence. Br J Surg 1986; 73: 404-7.

6 Henry MM, Swash M. Coloproctology and the pelvic floor. London: Butterworths, 1985: 417.

7 Neill ME, Parks AG, Swash M. Physiological studies of the pelvic floor in idiopathic faecal incontinence and rectal prolapse. Br J Surg 1981; 68: 531-6.

8 Read NW, Harford Wv, Schmulen AC, Read AG, Santa Ana C, Fordtran JS. A clinical study of patients with fecal incontinence and diarrhea. Gastroenterology 1979; 76: 747-56.

9 Duthie HL, Watts JM. Contribution of the external anal sphincter to the pressure zone in the anal canal. Gut 1965; 6: 64-8.

10 Frenckner B, von Euler C. Influence of pudendal block on the function of the anal sphincters. Gut 1976; 16: 482-9.

11 Lubowski DZ. Nicholls RJ, Burleigh DE, Swash M. The internal anal sphincter in neurogenic faecal incontinence. Gastroenterology 1988 (In press).

12 Kiff ES, Swash M. Slowed conduction in the pudendal nerves in idiopathic (neurogenic) incontinence. $\mathrm{Br} J$ Surg 1984; 71: 614-6.

13 Snooks SJ, Barnes PRH, Swash M. Damage to the innervation of the voluntary anal and periurethral sphincter musculature in incontinence. $J$ Neurol Neurosurg Psychiatry 1984; 47: 1269-73.

14 Snooks SJ, Henry MM, Swash M. Abnormalities in central and peripheral nerve conduction in anorectal incontinence. J R Soc Med 1985; 78: 294-300.

15 Henry MM, Snooks SJ, Barnes PRH, Swash M. Investigation of disorders of the anorectum and colon. Ann $R$ Coll Surg Engl 1985; 67: 355-60.

16 Gabella G. Smooth muscle cell junctions and structural aspects of contraction. Br Med Bull 1979; 35: 213-8.

17 Gabella G. Structure of smooth muscles. In: Bulbring E, Brading AF, Jones AW, Tomita T, eds. Smooth muscle; an assessment of current knowledge. London: Edward Arnold, 1981: 24-31.

18 Henderson RM. Types of cell contacts in arterial smooth muscle. Experientia 1975; 31: 103-5.

19 Gabella G. Dynamic aspects of the morphology of the intestinal muscle coat. In: Szurszewski JH, ed. Cellular physiology and clinical studies of gastrointestinal smooth muscle. Amsterdam: Excerpta Medica, 1987: 5-32.

20 Henry MM, Parks AG, Swash M. The pelvic floor musculature in the descending perineum syndrome. $\mathrm{BrJ}$ Surg 1982; 69: 470-2.

21 Parks AG. Anorectal incontinence. J R Soc Med 1975; 68: $681-90$.

22 Bartolo DCC, Roe AM, Locke-Edmunds JC, Virjee J, Mortensen NJMcC. Flap-valve theory of anorectal continence. Br J Surg 1986; 73: 1012-4. 
23 Read NW. The pathophysiology of anal leakage. In: Hoedmaker HO ten Cate, Gooszen HG, Mevr IT, eds. Faecal incontinence. Leiden: Weterman, 1985: 29-31.

24 Bartolo DCC. Miller R, Mortensen NJMcC. Sphincteric mechanism of anorectal continence during Valsalva manoeuvres. Coloproctology 1987; 9: 103-7.
25 Duthie HL, Gairns FW. Sensory nerve endings and sensation in the anal region of man. Br J Surg 1960; 47: 585-94.

26 Rogers J, Henry MM, Misiewicz JJ. Combined sensory and motor deficit in primary neuropathic faecal incontinence. Gut 1988; 29: 5-9. 


\section{Correction}

We regret that in the article by Swash et al (Gut 1988; 29: 1692-8) Figures 1 and 6 were duplicated and the correct Figure 1 is printed below.

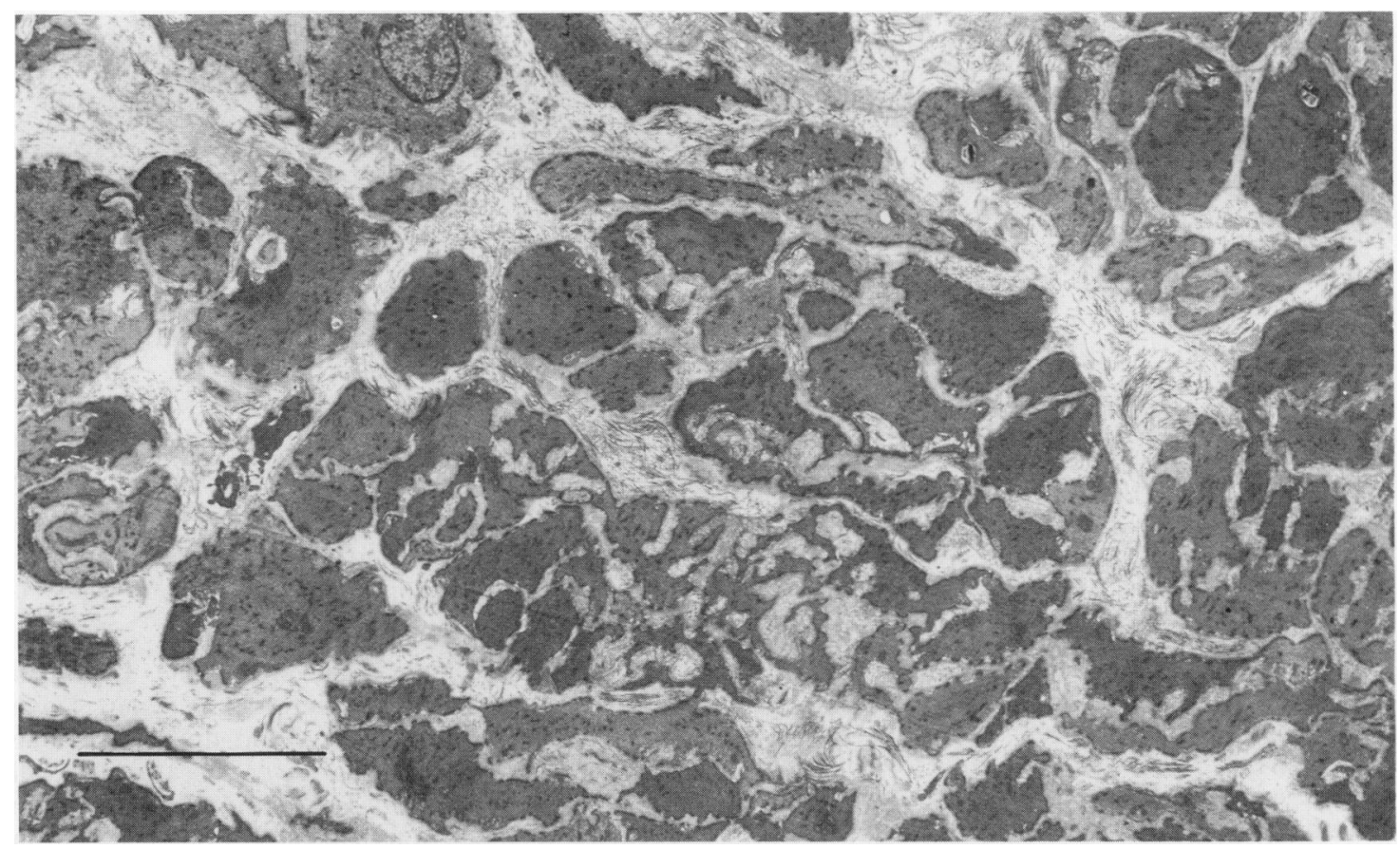

Fig. 1 Internal anal sphincter muscle in aged control subject. Lobular arrangement of smooth muscle cells is present, but there are increased amounts of collagen in the interstitial spaces. There is marked variability in size and electron density of the smooth muscle cells. Bar $10 \mu \mathrm{m}$. 